\title{
Analisis Faktor Risiko Kejadian Diabetes Mellitus Tipe II di Wilayah Pedesaan
}

\author{
Tias Tri Nurbaiti ${ }^{1}$, Arrum Firda Ayu Maqfiroch ${ }^{1}$, Siwi Pramatama Mars Wijayanti ${ }^{1}$ \\ ${ }^{1}$ Fakultas Ilmu-ilmu Kesehatan Universitas Jenderal Soedirman
}

\section{ABSTRACT}

Background: Diabetes mellitus (DM) is a non-communicable disease that remains a significant health concern in Indonesia. The disease is more prevalent in urban areas due to lifestyles, socioeconomics level and lack of physical activity. Currently, DM has begun occured also in rural areas. The purpose of this study is to identify the risk factors associated with Type II DM incidence in rural areas.

Method: This is analytical study with a case-control design, located in Community Health Centre 1, Wangon, Banyumas Regency. There are 65 people in case group and 65 people in control group involved in this study. Variables included personal characteristics, dietary habit, physical activity and exposure to cigarette smoke. Data was obtained by structured questionnaire and analyze using univariate, bivariate (chi-square test) and multivariate analysis (logistic regression test).

Results: The results showed that the dietary habit $(O R=11,824 ; 95 \% C I=4,988$ 28,032) and physical activity $(O R=2,608 ; 95 \% C I=1,116-6,095)$ had influenced on the incidence of DM type II. Whilst the exposure of cigarette smoking did not influenced the incidence of DM type II. It is suggested that consume foods with balanced nutrition and doing physical activities should be conducted routinely in accordance with $\mathrm{WHO}$ recommendations.
Correspondence

siwimars@gmail.com

\section{Article History}

Received 6 December 2019

Revised 29 January 2020

Accepted 9 January 2020

Available Online 6 March 2020

Keywords

Diabetes mellitus

Dietary habit

Physical activity

DOI

10.14710/jpki.15.1.16-21

\section{PENDAHULUAN}

Penyakit Diabetes Mellitus (DM) sampai saat ini masih menjadi permasalahan kesehatan penting di Indonesia, karena kasusnya yang terus terjadi. Data dari International Diabetes Federation pada tahun 2017 menyebutkan bahwa Indonesia menduduki peringkat ke-6 negara dengan jumlah orang dengan diabetes terbanyak. ${ }^{1}$ Penyakit ini merupakan penyakit metabolik yang ditandai dengan hiperglikemia kronis yang diakibatkan karena kerusakan/defisiensi sekresi insulin, kerusakan respon terhadap hormon insulin ataupun keduanya. Penyakit ini terbagi menjadi DM Tipe I, Tipe II dan Tipe gestasional. DM Tipe II merupakan tipe yang paling banyak ditemukan karena berhubungan dengan gaya hidup dan pola makan seseorang. ${ }^{2}$

Menurut Federasi Diabetes Internasional, 415 juta orang hidup dengan DM Tipe II pada tahun 2015, dan diperkirakan jumlahnya akan meningkat menjadi hampir 642 juta pada tahun 2040. Data epidemiologis memprediksi peningkatan beban pengeluaran kesehatan global yang tidak dapat dihindari akibat dari penyakit DM Tipe II, sehingga pencegahan penyakit harus menjadi prioritas. Diabetes Tipe II disebabkan oleh interaksi antara faktor genetik dan lingkungan. Gen dan lingkungan seperti perilaku dan gaya hidup secara bersama-sama merupakan penentu terjadinya resistensi insulin dan disfungsi sel $\beta$ pankreas. ${ }^{3}$

Berdasar review penelitian-penelitian sebelumnya, dilaporkan terdapat beberapa faktor seperti pola diet yang tidak sehat (peningkatan konsumsi daging dan gula olahan) minuman manis, penurunan asupan biji-bijian utuh, kopi dan besi heme, serta rendahnya kepatuhan terhadap pola makan yang sehat berhubungan dengan kejadian DM Tipe II. Rendahnya tingkat pendidikan dan kesadaran, penurunan aktivitas fisik, merokok, polusi udara, dan beberapa kondisi medis (tekanan darah sistolik tinggi, usia menarche lanjut, diabetes gestasional, sindrom metabolik, kelahiran prematur juga meningkatkan risiko terjadinya penyakit DM. ${ }^{4}$

Faktor-faktor risiko yang berhubungan dengan DM tipe II terdapat faktor risiko yang tidak dapat dimodifikasi/diubah dan faktor risiko yang dapat dimodifikasi/diubah. Faktor riwayat keluarga ataupun genetis merupakan variabel yang tidak dapat diubah. ${ }^{5}$ Beberapa penelitian menyebutkan faktor risiko yang dapat dimodifikasi seperti obesitas, kurangnya aktivitas fisik, merokok, hipertensi, dislipidemi dan diet tidak sehat. ${ }^{6,7}$ Kasus DM tipe II dapat dicegah dengan perubahan gaya hidup seperti menjaga berat badan, beraktivitas fisik, tidak merokok dan tidak minum minuman beralkohol. ${ }^{8}$ Faktor 
risiko yang dapat diubah menarik untuk ditelaah lebih dalam, karena dengan mengetahui faktor risiko yang dapat diubah, masyarakat bisa melakukan upaya pencegahan terhadap DM khususnya DM tipe II.

Data epidemiologi penyakit DM menunjukkan kasusnya cenderung lebih banyak terjadi di wilayah perkotaan dibanding wilayah pedesaan. Berdasarkan data Riskesdas Tahun 2018, prevalensi DM lebih tinggi di daerah perkotaan $(2,6 \%)$ daripada di daerah pedesaan $(1,4 \%)$. Hal tersebut dikaitkan dengan gaya hidup, di mana masyarakat di daerah urban cenderung memiliki gaya hidup yang tidak sehat. Masyarakat perkotaan lebih banyak mengonsumsi makanan cepat saji dan jarang melakukan aktivitas fisik. Masyarakat yang kurang melakukan aktivitas fisik di daerah pedesaan sebesar $42,4 \%$ sementara di daerah perkotaan lebih banyak yakni mencapai $57,6 \% .^{9}$ Penelitian di negara lain juga masih menyebutkan hal yang sama. ${ }^{10}$

Perkembangan terkini menunjukkan bahwa penyakit DM makin banyak juga ditemukan di wilayah pedesaan. ${ }^{11,12}$ Hal ini tentu saja menarik untuk dikaji lebih lanjut, karena belum banyak informasi mengenai faktor risiko kejadian DM di wilayah pedesaan, terutama faktor risiko yang dapat dimodifikasi. Tujuan penelitian ini adalah untuk mengetahui faktor-faktor risiko kejadian DM yang dapat dimodifikasi di wilayah pedesaan. Area studi yang dipilih yakni wilayah kerja Puskesmas Wangon I karena termasuk ke dalam wilayah pedesaan, namun data menunjukkan kasus penyakit DM-nya selalu meningkat setiap tahunnya. Berdasar data dari Puskesmas I Wangon, sampai dengan bulan Oktober 2018 terdapat 128 pasien DM yang mengikuti kegiatan prolanis (program pengelolaan penyakit kronis).

\section{METODE}

Penelitian ini adalah penelitian epidemiologi analitik dengan menggunakan desain studi kasus kontrol yang berlokasi di wilayah kerja Puskesmas I Wangon, Kabupaten Banyumas. Populasi kasus dalam penelitian ini yaitu seluruh penderita DM di wilayah kerja Puskesmas I Wangon yang menderita DM tipe II sejumlah 128 orang. Kriteria inklusi kelompok kasus yakni pasien DM Tipe II yang didiagnosis 2 tahun terakhir, bertempat tinggal di wilayah kerja Puskesmas I Wangon. Kriteria eksklusi yakni pasien meninggal dunia, atau tidak bersedia menjadi responden. Teknik pengambilan sampel pada kelompok kasus menggunakan accidental sampling yakni sampel dipilih dari peserta prolanis yang datang saat kegiatan prolanis di Puskesmas I Wangon, yang memenuhi kriteria inklusi dan eksklusi.

Populasi kontrol yaitu seluruh warga yang tinggal di wilayah kerja Puskesmas I Wangon yang tidak menderita Diabetes Mellitus tipe II. Kelompok kontrol diambil dengan teknik purposive sampling yakni pasien yang memeriksakan diri ke Puskesmas I Wangon, tidak menderita DM dan mempunyai ciri yang relative sama dengan kelompok intervensi. Besar sampel pada penelitian ini menggunakan rumus Lapau sehingga didapatkan besar sampel sebanyak 65 orang. Penelitian ini menggunakan perbandingan kasus dan kontrol 1:1, sehingga sampel dalam penelitian ini terdiri dari kelompok kasus 65 orang dan kelompok kontrol 65 orang. Variabel independen meliputi karakteristik responden, pola makan, aktivitas fisik dan keterpaparan asap rokok. Data dikumpulkan melalui wawancara dengan kuesioner. Kuesioner yang digunakan dalam penelitian ini menggunakan kuesioner baku, yakni kuesioner aktivitas fisik merujuk pada Global Physical Activity Questionnaire (GPAQ) dari WHO yang dilengkapi dengan kartu contoh. ${ }^{13}$ Kemudian untuk kuesioner pola makan menggunakan food frequency questionnaire. ${ }^{14}$ Analisis data dilakukan dengan analisis univariat, analisis bivariat dengan Chi Square dan analisis multivariat dengan regresi logistik.

Penelitian ini mendapatkan surat keterangan kelaikan etik (Ethical Clearence) dari Komisi Etik Penelitian Kesehatan Fakultas Kedokteran UNSOED nomor 1395/UN23.07.5.1/PP.1/2019. Identititas pasien tidak dimasukkan untuk menjaga kerahasiaan.

\section{HASIL DAN PEMBAHASAN}

Karakteristik responden kasus dan kontrol pada penelitian ini yakni sebagian besar berjenis kelamin perempuan, berpendidikan dasar dan bekerja sebagai ibu rumah tangga. Sebanyak 55,4\% kelompok kasus mempunyai riwayat keluarga dengan DM, sementara hanya $6,2 \%$ saja di kelompok kontrol yang menyatakan mempunyai riwayat keluarga dengan DM. Secara rinci, karakteristik responden pada penelitian ini terdapat pada Tabel 1. Berdasarkan hasil analisis bivariat, diperoleh hasil faktor risiko yang dapat dimodifikasi yang berhubungan dengan DM tipe II adalah pola makan, aktivitas fisik dan keterpaparan asap rokok (Tabel 2). Analisis multivariat menunjukkan bahwa pola makan dan aktivitas fisik yang merupakan faktor yang mempengaruhi kejadian DM di wilayah studi (Tabel 3).

Variabel yang memiliki pengaruh besar terhadap kejadian DM tipe II di Puskesmas I Wangon adalah pola makan. Hasil analisis didapatkan Odds Ratio (OR) dari variabel pola makan yang berisiko adalah 11,8 (95\% CI: $4,988-28,032)$, artinya orang yang memiliki pola makan berisiko 11,8 kali lebih besar untuk terkena DM tipe II dibandingkan dengan orang yang memiliki pola makan tidak berisiko. Pola makan yang berisiko adalah pola makan yang sering mengkonsumsi sumber makanan tinggi karbohidrat (nasi, roti dan mie), minuman dan makanan manis, daging berlemak, sumber lemak, makanan cepat saji serta makanan yang diawetkan. ${ }^{15}$ Hasil penelitian ini sejalan dengan 
penelitian sebelumnya yang menyatakan bahwa responden yang memiliki pola makan buruk berisiko lebih besar untuk terkena Diabetes Mellitus (DM) tipe II dibandingkan dengan responden yang pola makannya baik. ${ }^{16}$

Pengelolaan pola makan merupakan kunci utama pada kontrol glikemik yang baik pada penyakit DM. Rekomendasi umum saat ini yakni konsumsi karbohidrat sekitar 45\%-65\% dari asupan kalori harian, lemak sekitar
25\%-35\% dari total kalori harian dan protein sekitar 15\%$20 \%$ dari total kalori harian. Transisi dari pola konsumsi makanan lokal dengan pengolahan makan yang baik ke pola konsumsi junk food diperkirakan menjadi penyebab kebiasaan makan yang buruk. Data menyebutkan adanya peningkatan eksponensial dalam jumlah makanan cepat saji, yang berkontribusi pada pola diet tidak sehat dengan kandungan kalori tinggi dan lemak tidak sehat. ${ }^{17}$

Tabel 1. Distribusi frekuensi karakteristik responden

\begin{tabular}{|c|c|c|c|c|c|}
\hline \multirow{2}{*}{\multicolumn{2}{|c|}{ Karakteristik Responden }} & \multicolumn{2}{|c|}{ Kasus } & \multicolumn{2}{|c|}{ Kontrol } \\
\hline & & $\mathbf{n}$ & $\%$ & $\mathbf{n}$ & $\%$ \\
\hline \multirow[t]{2}{*}{ Jenis Kelamin } & Laki-laki & 5 & 7,7 & 5 & 7,7 \\
\hline & Perempuan & 60 & 92,3 & 60 & 92,3 \\
\hline \multirow[t]{3}{*}{ Pendidikan } & Dasar (SD/MI-SMP/MTs) & 54 & 83,1 & 57 & 87,7 \\
\hline & Menengah (SMA/MA/SMK) & 9 & 13,8 & 7 & 10,8 \\
\hline & Tinggi (Diploma, S1, S2) & 2 & 3,1 & 1 & 1,5 \\
\hline \multirow[t]{6}{*}{ Pekerjaan } & Pedagang & 6 & 9,2 & 8 & 12,3 \\
\hline & Buruh/Tani & 17 & 26,2 & 21 & 32,2 \\
\hline & PNS & 1 & 1,5 & 1 & 1,5 \\
\hline & Pensiunan & 1 & 1,5 & 0 & 0 \\
\hline & Wiraswasta & 6 & 9,2 & 1 & 1,5 \\
\hline & Ibu Rumah Tangga & 34 & 52,3 & 34 & 52,3 \\
\hline \multirow[t]{2}{*}{ Penghasilan } & $\leq \mathrm{UMK}$ Kab. Banyumas & 43 & 66,2 & 44 & 67,7 \\
\hline & >UMK Kab. Banyumas & 22 & 33,8 & 21 & 32,3 \\
\hline \multirow[t]{2}{*}{ Riwayat DM Keluarga } & Ada & 36 & 55,4 & 4 & 6,2 \\
\hline & Tidak Ada & 29 & 44,6 & 61 & 93,8 \\
\hline
\end{tabular}

Tabel 2. Faktor yang berhubungan dengan DM tipe II di Wilayah Puskesmas I Wangon

\begin{tabular}{|c|c|c|c|c|c|c|c|c|}
\hline \multirow{3}{*}{ Variabel } & \multicolumn{4}{|c|}{ Kelompok } & \multirow{2}{*}{\multicolumn{2}{|c|}{ Jumlah }} & \multirow{3}{*}{ p-value } & \multirow{3}{*}{$\begin{array}{c}\text { OR } \\
(95 \% \mathrm{CI})\end{array}$} \\
\hline & \multicolumn{2}{|c|}{ Kasus } & \multicolumn{2}{|c|}{ Kontrol } & & & & \\
\hline & $\mathbf{n}$ & $\%$ & $\mathbf{n}$ & $\%$ & $\mathbf{n}$ & $\%$ & & \\
\hline \multicolumn{9}{|l|}{ Pola Makan } \\
\hline Berisiko & 47 & 72,3 & 11 & 16,9 & 58 & 44,6 & \multirow{3}{*}{0,000} & \multirow{3}{*}{$\begin{array}{c}12,818 \\
(5,501-29,867)\end{array}$} \\
\hline Tidak Berisiko & 18 & 27,7 & 54 & 83,1 & 72 & 55,4 & & \\
\hline Total & 65 & 100,0 & 65 & 100,0 & 130 & 100,0 & & \\
\hline \multicolumn{9}{|l|}{ Aktivitas Fisik } \\
\hline Rendah & 44 & 67,7 & 26 & 40,0 & 70 & 53,8 & \multirow{3}{*}{0,003} & \multirow{3}{*}{$\begin{array}{c}3,143 \\
(1,532-6,448)\end{array}$} \\
\hline Tinggi & 21 & 32,3 & 39 & 60,0 & 60 & 46,2 & & \\
\hline Total & 65 & 100,0 & 65 & 100,0 & 130 & 100,0 & & \\
\hline \multicolumn{9}{|c|}{ Keterpaparan Asap Rokok } \\
\hline Terpapar & 47 & 72,3 & 35 & 53,8 & 82 & 63,1 & \multirow{3}{*}{0,046} & \multirow{3}{*}{$\begin{array}{c}2,238 \\
(1,079-4,644)\end{array}$} \\
\hline Tidak Terpapar & 18 & 27,7 & 30 & 46,2 & 48 & 36,9 & & \\
\hline Total & 65 & 100,0 & 65 & 100,0 & 130 & 100,0 & & \\
\hline
\end{tabular}

Tabel 3. Hasil analisis multivariat

\begin{tabular}{lcccc}
\hline \multicolumn{1}{c}{ Faktor Risiko } & B & p-value & Exp(B) & 95\% CI \\
\hline Pola Makan Berisiko & 2,470 & 0,000 & 11,824 & $4,988-28,032$ \\
Aktivitas Fisik Rendah & 0,958 & 0,027 & 2,608 & $1,116-6,095$ \\
\hline
\end{tabular}


Faktor risiko utama terkait dengan diet pada kejadian DM tipe II adalah ketidakseimbangan gizi karena konsumsi tinggi karbohidrat, lemak dan kolesterol. Mengonsumsi nasi putih sebagai makanan pokok dan sumber utama kalori, dengan sedikit kandungan serat pada populasi masyarakat di Asia merupakan faktor risiko terkena DM tipe II. ${ }^{18}$ Ketika tubuh mengonsumsi kalori dan lemak ekstra dapat menciptakan peningkatan glukosa darah yang tidak diinginkan. Ketika kadar glukosa darah tidak dicek, hal itu dapat menyebabkan masalah serius, seperti kadar glukosa darah yang tinggi (hiperglikemia) yang jika persisten terjadi dapat menyebabkan komplikasi jangka panjang, seperti kerusakan saraf, ginjal, dan jantung. ${ }^{19}$

Hasil analisis multivariat menunjukkan bahwa aktivitas fisik yang rendah merupakan faktor yang berpengaruh terhadap kejadian DM tipe II. Berdasarkan analisis multivariat aktivitas fisik yang rendah mempengaruhi kejadian DM tipe II, dengan $p$ value $=0,027$ $(\mathrm{OR}=2,608 ; 95 \% \mathrm{CI}=1,116-6,095)$. Orang yang memiliki aktivitas fisik yang rendah memiliki risiko 2,608 kali lebih besar untuk terkena DM tipe II dibandingkan dengan orang yang aktivitas fisiknya tinggi. Hasil penelitian ini sejalan dengan penelitian sebelumnya yang menyatakan bahwa seseorang yang memiliki aktivitas fisik rendah berisiko untuk mengalami kejadian diabetes dibandingkan dengan orang yang memiliki aktivitas fisik yang tinggi. Penelitian sebelumnya menyebutkan bahwa orang dengan aktivitas fisik > $600 \mathrm{MET} /$ menit per minggu memiliki risiko terkena DM tipe II lebih rendah $26 \%$ bila dibandingkan dengan orang yang memiliki aktivitas fisik $\leq 600 \mathrm{MET} / \mathrm{menit}-$ minggu. ${ }^{20}$

Aktivitas fisik yang dilakukan seseorang akan dapat mempengaruhi kadar gulanya, karena penggunaan glukosa oleh otot akan meningkat ketika seseorang melakukan aktivitas fisik yang tinggi. Glukosa endogen akan meningkat untuk dapat menjaga kadar gula dalam darah tetap seimbang. Kebiasaan aktivitas fisik juga berhubungan dengan kecepatan pemulihan gula darah otot. Otot-otot di dalam tubuh akan bereaksi dengan menggunakan glukosa yang disimpannya sehingga kadar gula darah akan menurun. Beberapa aktivitas fisik seperti jogging, dilakukan selama 30-40 menit dapat meningkatkan pemasukan glukosa ke dalam sel sebesar 7 hingga 20 kali dibandingkan dengan tidak melakukan aktivitas tersebut. ${ }^{21}$

Aktivitas fisik rutin telah terbukti meningkatkan komposisi tubuh misalnya, melalui penurunan adipositas abdomen dan peningkatan kontrol berat badan, meningkatkan profil lipoprotein lipid (misalnya, melalui penurunan kadar trigliserida, peningkatan kadar kolesterol high-density lipoprotein (HDL) dan penurunan lipoprotein densitas rendah (Rasio LDL) ke HDL, meningkatkan homeostasis glukosa dan sensitivitas insulin, mengurangi tekanan darah, meningkatkan nada otonom, mengurangi peradangan sistemik, mengurangi pembekuan darah, meningkatkan aliran darah koroner, menambah fungsi jantung dan meningkatkan fungsi endotel. ${ }^{22}$ Nutrisi yang baik dan aktivitas fisik merupakan bagian penting dari gaya hidup sehat untuk dapat mencegah terjadinya diabetes karena dapat membantu menjaga kadar glukosa darah pada tubuh. ${ }^{23}$

Hasil analisis bivariat menunjukkan bahwa keterpaparan asap rokok berhubungan dengan kejadian DM tipe II dengan nilai $p$-value $0,046(\mathrm{OR}=2,238 ; 95 \% \mathrm{CI}=$ 1,079-4,644). Namun pada analisis multivariat, keterpaparan asap rokok bukan merupakan faktor yang berpengaruh terhadap kejadian DM tipe II. Hal ini tidak sejalan dengan penelitian sebelumnya yang menyatakan bahwa paparan ETS (Environmental Tobacco Smoke) meningkatkan risiko DM tipe II sebesar 50\% (95\%; CI=1,00-2,26). ${ }^{24}$ Studi kohort prospektif sebelumnya menunjukkan bahwa orang yang terpapar asap rokok 1,28 kali lebih berisiko terkena DM Tipe II dibandingkan dengan orang yang tidak terpapar asap rokok. $^{25}$

Tidak berpengaruhnya keterpaparan asap rokok dengan DM tipe II dalam penelitian ini dimungkinkan karena sebagian besar responden pada penelitian ini adalah perokok pasif. Status pajanan perokok pasif dilaporkan sendiri, sehingga ada kemungkinan responden cenderung untuk mempersempit status pajanan mereka dan ini dapat menyebabkan perkiraan risiko yang terlalu rendah atau melebih-lebihkan. Selain itu, responden yang memiliki anggota keluarga yang merokok pada kelompok kasus dan kontrol mempunyai proporsi yang hampir sama. Perilaku responden yang tidak menghindar ketika ada seseorang yang merokok didekatnya antara kelompok kasus (52,3\%) dan kelompok kontrol $(50,8 \%)$ hampir sama sehingga paparan antara kelompok kasus dan kontrol hampir merata.

Hasil penelitian ini mengungkapkan bahwa di wilayah pedesaan, ternyata faktor risiko yang teridentifikasi berhubungan dengan kejadian DM Tipe II yakni pola makan dan aktivitas fisik. Hal ini menunjukkan bahwa kemungkinan sudah terjadi transisi gaya hidup, bahwa wilayah pedesaan pun sudah mulai berubah pola konsumsi dan aktivitas fisiknya. Penduduk di wilayah pedesaan yang karakteristiknya lebih banyak bergantung pada pertanian, dahulu lebih sering mengkonsumsi makanan lokal yang diolah dengan baik. Namun sekarang ini pola makan penduduk pedesaan merupakan salah satu faktor risiko kejadian DM di wilayah tersebut. Demikian juga aktivitas fisik, penduduk desa seharusnya lebih banyak melakukan aktivitas fisik karena mayoritas penduduknya bekerja pada bidang pertanian. Kegiatan bertani dan berkebun seharusnya dapat menjadi aktivitas fisik regular pada penduduk desa. Namun ternyata pada penelitian ini pun teridentifikasi variabel yang hampir sama dengan kelompok wilayah perkotaan di mana aktivitas fisik yang rendah menjadi permasalahan meningkatnya risiko penyakit DM. 


\section{SIMPULAN}

Hasil penelitian ini menunjukkan adanya hubungan antara pola makan, aktivitas fisik dan keterpaparan asap rokok dengan kejadian DM tipe II. Faktor risiko yang dapat dimodifikasi yang berpengaruh terhadap DM tipe II di wilayah kerja Puskesmas I Wangon adalah pola makan dan aktivitas fisik. Orang dengan pola makan berisiko memiliki risiko 11,8 kali lebih besar untuk terkena DM tipe II dibandingkan dengan orang yang pola makannya tidak berisiko. Orang yang memiliki aktivitas fisik yang rendah memiliki risiko 2,6 kali lebih besar untuk terkena DM tipe II dibandingkan dengan orang yang aktivitas fisiknya tinggi. Hasil dari penelitian ini merekomendasikan untuk kembali menjaga pola makan yang baik dan beraktivitas fisik yang cukup untuk dapat menjaga kadar gula darah dalam tubuhnya sehingga kesehatannya tetap terjaga baik.

\section{KEPUSTAKAAN}

1. Federation ID. Diabetes Facts and Figure 2017. Available from: https://idf.org/aboutdiabetes/what-isdiabetes/facts-figures.html.

2. Blair M. Diabetes Mellitus Review. Urologic nursing. 2016;36(1):27-36.

3. Bellou V, Belbasis L, Tzoulaki I, Evangelou E. Risk factors for type 2 diabetes mellitus: An exposure-wide umbrella review of meta-analyses. PloS one. 2018;13(3):e0194127-e.DOI:

10.1371/journal.pone.0194127.

4. Issaka A, Paradies Y, Stevenson C. Modifiable and emerging risk factors for type 2 diabetes in Africa: a systematic review and meta-analysis protocol. Systematic Reviews. 2018;7(1):139.DOI: 10.1186/s13643-018-0801-y.

5. van Tilburg J, van Haeften TW, Pearson P, Wijmenga C. Defining the genetic contribution of type 2 diabetes mellitus. Journal of Medical Genetics. 2001;38(9):56978.DOI: 10.1136/jmg.38.9.569.

6. Bellou V, Belbasis L, Tzoulaki I, Evangelou E. Risk factors for type 2 diabetes mellitus: An exposure-wide umbrella review of meta-analyses. PLOS ONE. 2018;13(3):e0194127.DOI:

10.1371/journal.pone.0194127.

7. Murad MA, Abdulmageed SS, Iftikhar R, Sagga BK. Assessment of the Common Risk Factors Associated with Type 2 Diabetes Mellitus in Jeddah. International Journal of Endocrinology. 2014;2014:9.DOI: $10.1155 / 2014 / 616145$.

8. Sudargo T, Pertiwi S, Alexander R, Siswati T, Ernawati $Y$. The relationship between fried food consumption and physical activity with diabetes mellitus in Yogyakarta, Indonesia. International Journal Of Community Medicine And Public Health. 2016;4:38.DOI: 10.18203/2394-6040.ijcmph20164709.
9. RI K. Data Utama Riskesdas 2018 Jakarta: Kemenkes RI; 2018 [cited 2019]. Available from: http://www.kesmas.kemkes.go.id/assets/upload/dir_519 d41d8cd98f00/files/Hasil-riskesdas-2018_1274.pdf.

10. Aung WP, Htet AS, Bjertness E, Stigum H, Chongsuvivatwong V, Kjøllesdal MKR. Urban-rural differences in the prevalence of diabetes mellitus among 25-74 year-old adults of the Yangon Region, Myanmar: two cross-sectional studies. BMJ Open. 2018;8(3):e020406.DOI: $\quad$ 10.1136/bmjopen-2017020406.

11. Singh PS, Sharma H, Zafar KS, Singh PK, Yadav SK, Gautam RK, et al. Prevalence of type 2 diabetes mellitus in rural population of India- a study from Western Uttar Pradesh. 2017. 2017;5(4):5.DOI: 10.18203/23206012.ijrms20171227.

12. Vaz NC, Ferreira AM, Kulkarni MS, Vaz FS. Prevalence of diabetes mellitus in a rural population of Goa, India. The National medical journal of India. 2011;24(1):16-8.

13. WHO. Global Physical Activity Questionnaire (GPAQ) WHO; 2005.2 Available from: https://www.who.int/ncds/surveillance/steps/resources/ GPAQ_Analysis_Guide.pdf.

14. Sirajuddin M, Nadimin dan Suriani. Survei konsumsi pangan. Jakarta: Penerbit Buku Kedokteran EGC; 2015.

15. Sami W, Ansari T, Butt NS, Hamid MRA. Effect of diet on type 2 diabetes mellitus: A review. Int J Health Sci (Qassim). 2017;11(2):65-71.

16. Rahati S, Shahraki M, Arjomand G, Shahraki T. Food pattern, lifestyle and diabetes mellitus. Int J High Risk Behav Addict. 2014;3(1):e8725-e.DOI: 10.5812/ijhrba.8725.

17. Stanley N. Dietary Management of Diabetes Mellitus with Focus on Nigeria. 2019.DOI: 10.17554/j.issn.24142409.2019.02.14.

18. Nanditha A, Ma RCW, Ramachandran A, Snehalatha C, Chan JCN, Chia KS, et al. Diabetes in Asia and the Pacific: Implications for the Global Epidemic. Diabetes Care. 2016;39(3):472-85.DOI: 10.2337/dc15-1536.

19. Papatheodorou K, Banach M, Bekiari E, Rizzo M, Edmonds M. Complications of Diabetes 2017. J Diabetes Res. 2018;2018:3086167-.DOI: 10.1155/2018/3086167.

20. Smith AD, Crippa A, Woodcock J, Brage S. Physical activity and incident type 2 diabetes mellitus: a systematic review and dose-response meta-analysis of prospective cohort studies. Diabetologia. 2016;59(12):2527-45.DOI: 10.1007/s00125-016-40790.

21. Zhang D, Liu X, Liu Y, Sun X, Wang B, Ren Y, et al. Leisure-time physical activity and incident metabolic syndrome: a systematic review and dose-response meta- 
analysis of cohort studies. Metabolism: clinical and experimental. 2017;75:36-44.DOI: 10.1016/j.metabol.2017.08.001.

22. Subrata T, Lestarini A, Sari K. Physical Exercises Effectiveness in Controlling Diabetes Mellitus in the Elderly Group in Bali - Indonesia. IOP Conference Series: Materials Science and Engineering. 2018;434:012228.DOI: $\quad 10.1088 / 1757-$ 899X/434/1/012228.

23. Forouhi NG, Misra A, Mohan V, Taylor R, Yancy W. Dietary and nutritional approaches for prevention and management of type 2 diabetes. BMJ. 2018;361:k2234.DOI: 10.1136/bmj.k2234.

24. Eze IC, Schaffner E, Zemp E, von Eckardstein A, Turk A, Bettschart R, et al. Environmental tobacco smoke exposure and diabetes in adult never-smokers. Environmental health : a global access science source. 2014;13:74.DOI: 10.1186/1476-069x-13-74.

25. Wang Y, Ji J, Liu Y-j, Deng X, He Q-q. Passive Smoking and Risk of Type 2 Diabetes: A Meta-Analysis of Prospective Cohort Studies. PLOS ONE. 2013;8(7):e69915.DOI: 10.1371/journal.pone.0069915. 